\title{
Research into the Embedded Subject Service Model under the Ubiquitous Knowledge Environment
}

\author{
Xinyu Wang \\ library, \\ JiLin Agricultural University, \\ Changchun, China \\ Email: 729738677@qq.com
}

\author{
Qingsong Zhang \\ library, \\ JiLin Agricultural University, \\ Changchun, China \\ Email: 1007738301@qq.com
}

\begin{abstract}
Under the ubiquitous knowledge environment, the embedded subject service has become the development direction of the library subject service model. This paper analyzes the relationship between the ubiquitous knowledge environment and the embedded subject service, analyzes the definition of the embedded subject service model and puts forward corresponding service strategies at an attempt to provide references for the embedded subject service.
\end{abstract}

Keywords-embedded service; subject service; physical space ; virtual space ; Strategy

\section{INTRODUCTION}

With the advent of big data era, every trade goes into their own informatization periods correspondingly. There is no doubt that whether the retrieval or the use of information has brought unprecedented development to most users. Under this circumstances, university library, as an information collection place, should all the more take the lead. How to gather, organize, provide and use the information better so as to serve most information users better, under the current situation, will face new challenges. "Embedded Discipline Service" just comes into being in this environment. This service originated from foreign war correspondents, and then evolved into a service gradually. What is "Embedded Discipline Service"? Its core refers to that facing with current information environment as well as the new situation of the knowledge innovation, university library, as a result, integrates its service into the user's environment actively, helping the users provide the service for research, teaching and learning. Broadly speaking, the purpose of Embedded Discipline Service is providing a guarantee for the information environment for uses' personalized information demand.

\section{EMBEDDED SUBJECT SERVICE-A REQUIREMENT OF LIBRARIES TO IMPROVE THE SERVICE QUALITY UNDER THE UBIQUITOUS KNOWLEDGE ENVIRONMENT}

Under the ubiquitous knowledge environment, the embedded subject service has become the development direction of the future library service model. Being user-demand driven, it aims at building an information assurance environment meeting users' personalized information demands, providing one-stop intensive information services by embedding subject information service and information resources organically into users' physical space and virtual environment, and creating a brand-new operation mechanism through structure adjustment, service upgrade and resource allocation. In the automatic interactive and open information exchange model, library resources and services have become an important part of users' information activities. The previous implicit, scattered and discrete information service has been turned into an explicit, centralized and deposited one, thus achieving the goal of service iniquity and accessibility ${ }^{[1]}$. The social mission and service essence of libraries is to improve their influence on teaching practices and scientific research. In the dynamic subject knowledge community featuring knowledge aggregation, processing, exchange and dissemination, the academic research teams and individuals convey their subject service demands in terms of scientific research, quality training, intelligence service and reference consultation to subject librarians. Subject librarians comprehensively embed information, knowledge and intelligence into the research activities of the above research subjects through paths, including resources, processes, emotions and techniques. Based on the feedback of the research subjects about the subject service quality, libraries and subject librarians keep on improving service strategies, service space layout and service quality ${ }^{[2]}$.

\section{DEFINITION OF THE EMBEDDED SUBJECT SERVICE}

Embedded subject service refers to the in-depth subject information service conducted by embedding information into users' physical and virtual space through various information techniques and approaches.

\section{A. Embedded subject service based on the physical space}

Embed teachers' teaching environment

In order to realize the goal of expanding and extending library subject services, subject librarians should actively integrate themselves into the teaching process of teachers. Subject libraries can provide personalized and professional information resource services by working closely with teachers, assisting teachers in finishing the design, organization, implementation and evaluation of courses, practices and other activities, and providing one-stop services for the whole teaching process. There are two ways for subject librarians to embed teachers' teaching environment into subject service. First, rely on the rich library resources, employ the modern information 
techniques to search and assort the cutting-edge subject trends and development, and provide teachers with all-around quality resources support for teachers' teaching practices; give targeted information education to teachers and students so as to make them familiar with literature retrieval techniques and methods and improve their information application ability. Second, embed the information quality education into the teaching content with teaching goals, teaching content and teaching methods formulated jointly by subject librarians and lecturers and one to two courses held by subject librarians to focus on recommending library subject resources and information services. The embedded teaching services can improve the information qualities of teachers and students, and deepen the relationship between libraries and departments ${ }^{[3]}$.

Embed users' scientific research environment

Based on the quantitative and qualitative analysis of the academic foreland and development status quo, subject librarians integrate themselves into users' scientific research environment as subject research partners to conduct embedded subject services. By employing modern information techniques to search and analyze information resources, subject librarians provide quality and targeted academic research information with high referential value and knowledge value-added services for major scientific research users. In research topic selection, application, research progress, research finding verification and application, subject librarians provide one-stop information services and knowledge services so as to meet users' knowledge demands and assist users in efficiently finishing subject research projects and application of research achievements. In the whole knowledge service process, subject librarians enhance the accumulation of professional knowledge and scientific research qualities, improve their subject service capability and achieve a win-win pattern with users.

\section{B. Embedded subject service based on the virtual space}

The embedded subject service based on the virtual space can get rid of the limits of time and space. Through human-computer interaction, users can the visible, convenient, quality and efficient services of librarians. Below are several service methods: 1) Embed the information resources and subject services of libraries into iPads, mobiles, learning machines, readers and intelligent devices: Based on characteristics of the above devices, namely high popularity, convenience and diversified functions, the mobile new book notification, reference consulting, borrow information inquiry and database retrieval can be realized. In this way, users can learn at any time and any place; 2) Provide the RSS personalized recommendation services: Employ the web2.0 technique to achieve subject information RSS and recommend library subject information and specialized information to the users' desktop; 3) Establish subject blogs and QQ groups, create the interactive academic community and lead readers to send their feedback; 4) Embed the shortcut menu into users' commonly-used software and websites, and allow users to have convenient access to library services without logging on the library websites.

\section{IMPLEMENTATION STRATEGIES OF THE EMBEDDED SUBJECT SERVICE}

\section{A. Innovate concepts, master user demands, and conduct top-level design of the subject service}

Concept innovation is a critical element to the embedded subject services. With users at the core, university and college libraries should form the user-demand-driven service concept, and plan the theoretical system, top-level design and service procedures of the embedded subject services; master the characteristics and trends of user demands; transform personnel and organizational institutions; re-plan the information resource layout; build a subject service platform featuring the combination of physical and virtual space; optimize the subject service strategies; expand the subject service channels; and form a mechanism genuinely serving users by embedding subject service into users' teaching and scientific research environment through various ways. In this way, libraries can, on the one hand, provide efficient, quality, personalized and in-depth subject services for users; on the other hand, realize their own value.

\section{B. Coordinate various parties, re-organize a subject service team and create a service assurance system}

Coordinate various parties to conduct an all-around implementation of the embedded subject service based on the service-oriented concept. Seek the support of schools' administrative departments to institutionalize the embedded subject service. This is an important guarantee for the smooth progress and normalization of activities. Seek the cooperation with the other information service institutions under the principle of mutual benefits and jointly promote the subject service. Subject librarians should get rid of the traditional shackles of libraries to embed the subject service into users' teaching and scientific research environment through various ways, and obtain the active support of user groups. Enhance the unity and coordination between various departments within libraries, create an optimistic organizational culture, enhance communication and exchange based on the functionalized coordination, and improve the overall subject service level. An optimistic subject librarian team is of vital importance to the implementation of subject service. Organize a subject service team featuring the coordination of departments of circulation, journal, reference consulting, interview, catalog and network techniques. The subject service team can jointly finish the tasks of subject connection, knowledge organization, information recommendation, resource recommendation and personalized services. The team members should have a strong sense of responsibility, a professional knowledge system, a pioneering spirit and 
good interpersonal communication abilities; know the development direction and latest research trend of certain subject, clarify the distribution and allocation of subject resources and improve the capability of obtaining, collecting and utilizing information. Therefore, various ways should be adopted to enhance the subject service team construction and improve their service abilities and self-qualities $^{[4]}$.

\section{Rely on techniques, innovate service methods and enrich the connotation of subject service}

Advanced and comprehensive service techniques are important conditions for libraries' realization of subject service. Information and communication technology can be employed to build the computer operation environment and the user interaction platform so as to provide uses with the information resource navigation and enhance the communication and interaction with users, through BBS, RSS, QQ, Blog and E-mail, so as to enhance the systematic and real-time nature of subject service. Mobile techniques can improve the use efficiency and value of library services and resources. The integration strategy can fulfil various information retrievals between knowledge and heterogeneous database. By analyzing and processing daily circulating data, the data mining technology can dig the in-depth value of library knowledge resources. Subject librarians can dig, store, process and issue knowledge resources through information and communication technology, effectively integrate them into users' teaching and scientific research environment, conduct subject service in a targeted way and improve the overall service level of libraries $^{[5]}$.

\section{CONCLUSIONS}

The ubiquitous knowledge environment has brought new development opportunities for libraries. The embedded subject service with user demands at the core has become the shining and growth point of the subject service under the new information environment. By transforming the service concept, innovating the service form and building the service platform, it provides a brand-new construction perspective for the improvement of libraries' knowledge service capability, school's core competence and the local economy.

\section{ACKNOWLEDGMENT}

This paper is the periodical achievement of the research project of "In-depth integration and recommendation of library resources under the big data background" (Project No.: 2015019) in 2015 of CALIS China Agriculture Literature and Information Center.

\section{REFERENCES}

[1] XieShoumei.Study of Embedded Subject Service under Ubiquitous Knowledge Environment[J].Library Work and Study,2013, (1) : 27-42.
[2] Zhang Delin. User Embedded Subject Service in Academic Libraries[J].Journal of Library Science, 2012, (1) : 100-101.

[3] Yang Weiqi. Embedded Discipline-Oriented Service: the New Idea on Transformation and Development of Research University Libraries [J].Information and Documentation Services,2012, (2) : 88-92.

[4] Tian Fang. Study on Embedded Subject Services in University Libraries [J].Journal of Library and Information Sciences in Agriculture, 2012, (7) :205-208.

[5] Chen Quansong. Practice and Thoughts of Embedded Subject Service at University Libraries [J].Library and Information Service, 2012, (4) : 83-87. 